
3 Research Square
Preprints are preliminary reports that have not undergone peer review.
They should not be considered conclusive, used to inform clinical practice,
or referenced by the media as validated information.

\title{
Southwestern ponderosa pine forest patterns following wildland fires managed for resource benefit differ from reference landscapes
}

Jonathon James Donager ( $\nabla$ jonathon.donager@gmail.com )

Northern Arizona University Ecological Restoration Institute https://orcid.org/0000-0001-9448-1703

Andrew Joel Sánchez Meador

Northern Arizona University Ecological Restoration Institute

David William Huffman

Ecological Restoration Institute

\section{Research Article}

Keywords: Forest structure, frequent-fire forests, fire-adapted forest management, scale relationships, random forest classification, sentinel-2, resource management

Posted Date: June 2nd, 2021

DOI: https://doi.org/10.21203/rs.3.rs-171634/v1

License: (c) (i) This work is licensed under a Creative Commons Attribution 4.0 International License. Read Full License

Version of Record: A version of this preprint was published at Landscape Ecology on November 17th, 2021. See the published version at https://doi.org/10.1007/s10980-021-01352-1. 


\section{Abstract}

Context. Managers aiming to utilize wildland fire to restore southwestern ponderosa pine landscapes require better understanding of forest cover patterns produced at multiple scales. Restoration effectiveness of wildland fires managed for resource benefit can be evaluated against natural ranges of variation.

Objectives. We describe landscape patterns within reference landscapes, including restored and functioning ponderosa pine forests of northern Arizona, and compare them to wildland fires managed for resource benefit. We make comparisons along a gradient of extents and assess the effects of scale on landscape differences.

Methods. Using Sentinel-2 imagery, we classified ponderosa pine forest cover and calculated landscape metrics across a gradient of landscape extent within reference and managed landscapes. We used non-parametric tests to assess differences. We used random forest models to assess and explore which landscape metrics were most importance in differentiating landscape patterns.

Results. Managed wildfire landscapes were significantly different from reference landscapes for most metrics and extents (15 ha to 840 ha). Landscape type (managed vs. reference) became increasingly differentiable with scale, with area and aggregation metrics being the most informative. Classification models increased in accuracy despite fewer observations with increasing scale.

Conclusions. Wildland fires managed for resource benefit in ponderosa pine forests of northern Arizona are not producing landscape patterns consistent with reference landscapes likely due to predominance of low-severity burning and minimal resulting changes in overstory structure. Differences become more pronounced with increasing landscape size and suggest small-scale heterogeneity and mid - and large-scale homogeneity within each landscape type.

\section{Introduction}

In northern Arizona, USA, an extensive history of fire exclusion and the subsequent densification of ponderosa pine (Pinus ponderosa var. scopulorum P. \& C. Lawson) forest conditions have led to the need for landscape-scale restoration (Allen et al. 2002; Moore et al. 2004). It is well accepted that restoration of structure and ecological function is needed across large swaths of southwestern ponderosa pine forests (Allen et al. 2002; Churchill et al. 2013). Climate change, uncharacteristic wildfire, and other disturbances operating over spatial extents of thousands of hectares challenge public land managers to develop landscape-scale restoration plans. Restoration efforts typically utilize a combination of mechanical treatments, such as tree thinning to precisely and effectively meet structural objectives, yet these treatments can be costly and limited in scale and are not suitable for all lands (Hjerpe et al. 2009; Reynolds et al. 2013, North et al. 2015). Silvicultural prescriptions for mechanized restoration approaches are often guided by reference information, or descriptions of intact forest structure and processes (Fulé et al. 1997), but these treatments are prohibitively expensive across large scales. Such reference information is commonly used as a baseline against which effectiveness of various restoration approaches are evaluated (Morgan et al. 1994, White and Walker 1997, Landres et al. 1999). For southwestern ponderosa pine forests, natural ranges of variation have been well described for fine-scale (<10 acres) structural attributes, but there has been little work done to quantify landscape patterns among mid- (10 to 1000 acres) to landscape- (>1000 acres) scales of ecologically functioning forest stands and large restored sites (see Reynolds et al. 2013). An approach moving beyond typical plot-based comparisons is needed to capture the variability of landscape patterns across such a gradient of landscape scales and examine the current state of forest structure across the region.

Page 2/26 
To more economically treat the large forest areas needed for forest health, there is growing interest in using naturally occurring wildland fire as an additional or complementary treatment alternative (henceforth "managed wildfire") (North et al. 2012; Huffman et al. 2017, 2020). As frequent surface fire plays an integral role in regulation of structure and function in these ponderosa pine ecosystems, managed wildfires may provide a cost-effective approach for restoring contemporary forest conditions, including reduction in tree densities, lower hazardous fuel loads and potential fire behavior, and increased ecological resilience (Hunter et al. 2011; Ager et al. 2017; Fitch et al. 2018; Barros et al. 2018; Huffman et al. 2020). Moderate burn severity among both single- and multiple-entry managed wildfires meet more restoration objectives related to ponderosa pine forest structure, fuels, and ecological function, than areas in other burn severity classes, in northern Arizona and across western North America (Collins et al. 2011; Lydersen et al. 2013; Huffman et al. 2017, 2018, 2020; Stevens et al. 2017; Kane et al. 2019). However, the operational reality within the mosaic of multiuse lands is such that fire managers are typically averse to the risks associated with moderate-severity burning, resulting in the majority of reported treated acres falling into unburned and low-severity fire, which generally lack the ability to alter forest structure (Stephens et al. 2016; Huffman et al. 2017, 2018, 2020; Weber and Yadav 2020). Within southwestern ponderosa pine forests this has largely resulted in the lack of a mixed mosaic of mixed fire age and burn severities as would have existed historically. The relationship of fire severity and resulting forest structure has largely been studied at fine-scales using fixed area plots, typically less than one acre (Sánchez Meador et al. 2009, 2011; Huffman et al. 2017, 2018).

To place these managed wildfire landscapes in context, undisturbed, functioning or restored landscapes (hereafter referred to as reference landscapes) can provide estimates for a natural range of variability of landscape structure (White and Walker 1997; Fulé et al. 2002a; Collins et al. 2007, 2016). Contemporary restored forest conditions are particularly helpful for deriving landscape-scale reference information, as landscape metrics derived from the smallextent ( 0.04 ha to $1 \mathrm{ha}$ ) reconstructed canopy cover are difficult to extrapolate to larger extents (e.g. $800 \mathrm{ha})$ from historical data. Presently, few of these landscapes exist in the Southwest but notable exceptions include remote areas in national parks and wilderness areas, as well as large landscape with ongoing monitoring (Cocke et al. 2005). Unfortunately, what we might consider functioning forest landscapes is quite limited in its extent in northern Arizona. For this study, we chose to compare both ecologically functioning and ecologically restored landscapes, which together provide improved estimates of the natural range of variability for landscape metrics and baseline information for evaluating outcomes of managed wildfires in southwestern ponderosa forests.

The intent of this study was to quantify forest structure across a gradient of landscape scales to better understand spatial patterns within wildland fires managed for resource benefit and reference landscapes, consisting of restored and functioning ponderosa forests. From those metrics, we used a series of random forest models to better understand which components of landscape structure are driving the differences between these two landscape types and the scales at which those differences manifest. To accomplish this, we focused on three specific objectives: 1) quantify and test differences in landscape metrics calculated across a gradient of landscape extents among managed and reference landscapes, including restored and functioning landscapes 2) determine which landscape metrics are most important for distinguishing landscapes and identify how this relationship changes with landscape extent, and 3) interpret the management implications of multi-scale landscape metric differences among landscape types.

\section{Methods}

\subsection{Study Area}


We limited our study to reference and wildfire managed for resource benefit landscapes of interest within northern Arizona among federally controlled lands (Fig. 1). Reference landscapes included both intact and experimental restoration landscapes. We included four large reference landscapes (< $840 \mathrm{ha})$ and seven small ( $15 \mathrm{ha})$ experimental restoration areas in the study (Table 1). We compared these collectively described reference landscapes to 16 recent and sufficiently large managed fires which fit the study criteria (Fig. 1, Table 1). The sites encompassed a wide range of elevation, soil type, and topography, which in turn influences local climate. Average yearly precipitation ranges from 385 to $825 \mathrm{~mm}$ (1st and 99th percentiles of precipitation) and average temperatures range from 6.1 to $12.0{ }^{\circ} \mathrm{C}$ ( $1 \mathrm{st}$ and 99 th percentiles of temperature) when considering values within the distribution of ponderosa pine across the study area (PRISM Climate Group, accessed May 2020). Elevation within the distribution of ponderosa pine range from 1346 to $3449 \mathrm{~m}$ across the study extent. International soil classifications across the study area are generally Luvisols and Kastanozems (Hengl et al. 2017). We limited our study to the distribution of the "Rocky Mountain Ponderosa Pine Woodland" forest type land cover according to Southwest ReGAP data (SWReGAP 2005), as this represents forest cover dominated by ponderosa pine, but can include other components, including Gambel oak (Quercus gambellii). For a managed wildfire to be included in the study, the bounding polygon needed to be classified predominantly (2/3) as this forest type.

The four large reference landscapes for this study included Mt. Trumbull, a restored experimental landscape following Society of Ecological Restoration principles, initially treated with a thin/harvest treatment in 1996 to 1997 followed by initial prescribed fire and subsequent maintenance burning in 2000-2008 (Roccaforte et al. 2010); and Powell Plateau, Rainbow Plateau and Fire Point, three landscapes considered intact and ecologically functioning as logging and fire suppression have not occurred in large part due to their remoteness on the North Kaibab Plateau (Fulé et al. 2002a, 2004). Small experimental restoration sites (see Table 1) were treated using evidence-based ecological restoration guidelines ("ERG" sensu Tuten et al. 2015) wherein the resulting forest structure was targeted to be consistent with site-specific historical conditions and ranged (see Fulé et al. 2001, 2002b) in size from 8 to 15 ha (Table 1). These experimental sites located within Centennial Forest, Fort Valley Experimental Forest on the Coconino National Forest, and the Tusayan Ranger District (Fig. 1) of the Kaibab National Forest. All reference landscapes and restoration sites are dominated by ponderosa pine (Pinus ponderosa), but also include varying amounts of Gambel oak (Quercus gambelii).

We selected recent managed wildfires for analysis which met the following criteria: 1) size (> 405 ha), 2) year of occurrence between 2015 and 2018, 3) identified as being managed for resource benefit from the Forest Service Activity Tracking System (FACTS) database and 4) had a vegetation cover type dominated (>66\%) by ponderosa pine, as classified by the Southwest ReGAP land cover classification (Lowry et al. 2007). We cross-referenced selected fires with the Monitoring Trends in Burn Severity (MTBS) dataset to ensure the dates, locations, and perimeter of wildfires matched (MTBS 2017). A total of 16 wildfires matched all criteria (Fig. 1, Table 1). Fire weather and fuels information for each fire on the date of ignition is included in the Appendix (A). As our focus for this study was on ponderosa pine forest, we removed any fire meeting our criteria but not having a majority proportion of ponderosa pine forest cover (<66\%). Among the total burned area covered by the 16 wildfires, approximately $90 \%$ was classified as unburned and low severity, while medium and high severity classifications were $8.3 \%$ and $1.7 \%$, respectively (www.mtbs.gov). 
Table 1

Landscapes examined in the study, arranged from the smallest (restoration sites) to the largest (managed wildfires) landscapes considered. The percent area by fire severity (U: unburned, L: low, M: moderate, and H: high) was calculated from Monitoring Trends in Burn Severity (MTBS); dominant soil groups are an international soil classification for each area from SoilGrids data (Hengl et al. 2017); and mean climatic variables are 30-year averages from PRISM (PRISM Climate Group; 2020).

\begin{tabular}{|c|c|c|c|c|c|c|c|c|}
\hline $\begin{array}{l}\text { Landscape } \\
\text { type }\end{array}$ & Name & $\begin{array}{l}\text { Size } \\
\text { (ha) }\end{array}$ & $\begin{array}{l}\text { Treatment } \\
\text { Year }\end{array}$ & $\begin{array}{l}\text { Severity } \\
\% \\
\text { (U;L;M;H) }\end{array}$ & $\begin{array}{l}\text { Mean } \\
\text { Elevation } \\
(\mathrm{m})\end{array}$ & $\begin{array}{l}\text { Dominant } \\
\text { Soil Groups }\end{array}$ & $\begin{array}{l}\text { Mean } \\
\text { Temp } \\
\left({ }^{\circ} \mathrm{C}\right)\end{array}$ & $\begin{array}{l}\text { Mean } \\
\text { Precip } \\
(\mathrm{mm})\end{array}$ \\
\hline \multirow{7}{*}{$\begin{array}{l}\text { Restoration } \\
\text { Site }\end{array}$} & Tusayan 1 & 8.4 & 1999 & - & 2267.3 & Luvisols & 8.6 & 517.7 \\
\hline & Tusayan 2 & 11.9 & 1999 & - & 2259.5 & Luvisols & 8.6 & 511.8 \\
\hline & $\begin{array}{l}\text { Fort Valley } \\
1\end{array}$ & 15.2 & 2000 & - & 2336.2 & Luvisols & 6.9 & 624.0 \\
\hline & $\begin{array}{l}\text { Fort Valley } \\
2\end{array}$ & 12.8 & 2000 & - & 2326.9 & Luvisols & 6.9 & 620.6 \\
\hline & $\begin{array}{l}\text { Fort Valley } \\
3\end{array}$ & 14.2 & 2000 & - & 2266.9 & Luvisols & 7.0 & 584.5 \\
\hline & $\begin{array}{l}\text { Centennial } \\
\text { Forest } 1\end{array}$ & 11.2 & 2003 & - & 2242.7 & Luvisols & 7.1 & 574.1 \\
\hline & $\begin{array}{l}\text { Centennial } \\
\text { Forest } 2\end{array}$ & 11.9 & 2004 & - & 2201.1 & $\begin{array}{l}\text { Luvisols / } \\
\text { Kastanozems }\end{array}$ & 8.1 & 646.2 \\
\hline \multirow[t]{4}{*}{$\begin{array}{l}\text { Reference } \\
\text { Landscape }\end{array}$} & $\begin{array}{l}\text { Mt. } \\
\text { Trumbull }\end{array}$ & 701.1 & 2002 & - & 2125.1 & $\begin{array}{l}\text { Kastanozems } \\
\text { / Luvisols }\end{array}$ & 9.4 & 462.7 \\
\hline & $\begin{array}{l}\text { Powell } \\
\text { Plateau }\end{array}$ & 793.0 & - & - & 2242.4 & $\begin{array}{l}\text { Luvisols / } \\
\text { Kastanozems }\end{array}$ & 8.7 & 465.9 \\
\hline & $\begin{array}{l}\text { Rainbow } \\
\text { Plateau }\end{array}$ & 270.5 & - & - & 2257.1 & $\begin{array}{l}\text { Luvisols / } \\
\text { Kastanozems }\end{array}$ & 8.6 & 464.5 \\
\hline & Fire Point & 171.4 & - & - & 2282.6 & $\begin{array}{l}\text { Luvisols / } \\
\text { Kastanozems }\end{array}$ & 8.5 & 474.7 \\
\hline \multirow{8}{*}{$\begin{array}{l}\text { Resource } \\
\text { Objective } \\
\text { Wildfire }\end{array}$} & Fox & 452.3 & 2015 & $\begin{array}{l}\text { 67; 33; 0; } \\
0\end{array}$ & 1972.4 & Luvisols & 10.6 & 660.2 \\
\hline & Eden & 476.8 & 2016 & $\begin{array}{l}60 ; 31 ; 8 ; \\
1\end{array}$ & 2067.8 & Luvisols & 9.0 & 552.5 \\
\hline & Crackerbox & 514.4 & 2016 & $\begin{array}{l}64 ; 34 ; 0 \\
0\end{array}$ & 2152.4 & Luvisols & 8.9 & 652.2 \\
\hline & Echo & 810.0 & 2015 & $\begin{array}{l}66 ; 31 ; 3 \\
0\end{array}$ & 2079.2 & Luvisols & 9.8 & 704.9 \\
\hline & Cowboy & 860.8 & 2016 & $\begin{array}{l}60 ; 31 ; 8 ; \\
1\end{array}$ & 2133.2 & Luvisols & 8.6 & 736.6 \\
\hline & Rebel & 1017.7 & 2015 & $\begin{array}{l}65 ; 32 ; 3 \\
0\end{array}$ & 2195.4 & Luvisols & 8.7 & 611.5 \\
\hline & General & 1175.0 & 2015 & $\begin{array}{l}59 ; 35 ; 3 \\
0\end{array}$ & 2129.3 & Luvisols & 8.9 & 574.1 \\
\hline & Horse tank & 1558.2 & 2015 & $\begin{array}{l}57 ; 31 \\
10 ; 2\end{array}$ & 2067.7 & Luvisols & 10.7 & 720.9 \\
\hline
\end{tabular}




\begin{tabular}{|c|c|c|c|c|c|c|c|c|}
\hline $\begin{array}{l}\text { Landscape } \\
\text { type }\end{array}$ & Name & $\begin{array}{l}\text { Size } \\
\text { (ha) }\end{array}$ & $\begin{array}{l}\text { Treatment } \\
\text { Year }\end{array}$ & $\begin{array}{l}\text { Severity } \\
\% \\
\text { (U;L;M;H) }\end{array}$ & $\begin{array}{l}\text { Mean } \\
\text { Elevation } \\
\text { (m) }\end{array}$ & $\begin{array}{l}\text { Dominant } \\
\text { Soil Groups }\end{array}$ & $\begin{array}{l}\text { Mean } \\
\text { Temp } \\
\left({ }^{\circ} \mathrm{C}\right)\end{array}$ & $\begin{array}{l}\text { Mean } \\
\text { Precip } \\
(\mathrm{mm})\end{array}$ \\
\hline & Pinchot & 1562.8 & 2016 & $\begin{array}{l}59 ; 39 ; 2 ; \\
0\end{array}$ & 2205.7 & Luvisols & 9.0 & 695.4 \\
\hline & $\begin{array}{l}\text { Burnt } \\
\text { complex }\end{array}$ & 1663.7 & 2015 & $\begin{array}{l}64 ; 34 ; 2 ; \\
0\end{array}$ & 2366.2 & $\begin{array}{l}\text { Luvisols / } \\
\text { Chernozems }\end{array}$ & 8.2 & 558.0 \\
\hline & $\begin{array}{l}\text { Pine } \\
\text { hollow }\end{array}$ & 1718.3 & 2017 & $\begin{array}{l}68 ; 30 ; 2 ; \\
0\end{array}$ & 2219.7 & $\begin{array}{l}\text { Luvisols / } \\
\text { Kastanozems }\end{array}$ & 9.2 & 490.6 \\
\hline & Pivot rock & 2432.0 & 2016 & $55 ; 36 ; 8 ;$ & 2133.7 & Luvisols & 9.7 & 764.0 \\
\hline & Springs & 2997.9 & 2015 & $\begin{array}{l}67 ; 33 ; 0 ; \\
0\end{array}$ & 2144.9 & Luvisols & 9.1 & 638.2 \\
\hline & Mormon & 3193.7 & 2016 & $\begin{array}{l}54 ; 23 \\
19 ; 2\end{array}$ & 2205.6 & Luvisols & 8.0 & 709.8 \\
\hline & $\begin{array}{l}\text { Snake } \\
\text { ridge }\end{array}$ & 5713.5 & 2017 & $\begin{array}{l}68 ; 31 ; 1 ; \\
0\end{array}$ & 2074.6 & $\begin{array}{l}\text { Luvisols / } \\
\text { Kastanozems }\end{array}$ & 9.1 & 620.7 \\
\hline & Jack & 14527.8 & 2016 & $66 ; 25 ; 8 ;$ & 2146.6 & $\begin{array}{l}\text { Luvisols / } \\
\text { Kastanozems }\end{array}$ & 8.4 & 572.0 \\
\hline
\end{tabular}

\subsection{Canopy Cover Classification}

Quantifying forest structure over large areas is only possible through remote sensing approaches, which have a wellestablished role within forest research. Specifically, medium resolution $(10-100 \mathrm{~m})$ multi-spectral satellite imagery such as the Landsat family of satellites $(30 \mathrm{~m})$ or the Sentinel-2 satellites $(10-20 \mathrm{~m})$, provide frequent image coverage that can be used to monitor forest cover and dynamics (Eidenshink et al. 2007; Wulder et al. 2012; Li and Roy 2017). The quantification of forest structure from inter-stand (15ha) to landscape scales ( $>400 \mathrm{ha}$ ) is sensitive to the grain of the data used to quantify landscape metrics (Wasserman et al. 2019). Imagery from the Sentinel-2 satellites are medium-resolution (10-20m), multispectral (12 spectral band) datasets and provide wall-to-wall coverage every 5 days on average ( $\mathrm{Li}$ and Roy 2017). While sacrificing fine-scale (e.g., 1-3 $\mathrm{m}$ ) detail compared to higher-resolution datasets, which are often also limited to 4 multispectral bands, Sentinel-2 imagery allowed for increased discrimination of land cover types through integrating spectral and temporal information into the classification scheme (Li and Roy 2017).

We used seasonal image composites of Sentinel-2 satellite imagery to classify the landscape into four categories: evergreen canopy cover, deciduous canopy cover, non-tree cover and water. As our areas of interest were limited in extent, this simple classification scheme proved to be adequate to isolate ponderosa pine cover from deciduous cover, particularly Gambel oak. We built the seasonal image composites in Google Earth Engine (Gorelick et al. 2017) using Sentinel-2 level 2 A multispectral imagery calibrated to surface reflectance for the year 2019 . These images are radiometrically calibrated and geographically referenced. For each seasonal composite, we calculated the median value for each pixel after masking out cloud and cloud shadow pixels from the image stack using all available imagery in a time period that spanned one month prior to and following solstice and equinox dates. We conducted all subsequent analysis, including random forest classification models of the image composites in $\mathrm{R}$ using the ranger package (ver 0.12.1; Wright and Ziegler 2017) for random forest classification. Rasters representing 
elevation (http://ned.usgs.gov), derived slope and aspect as well as a soil parent material classification (Theobald et al. 2015) were included in the classification. We maintained the pixel resolution of the classification and resulting grain of landscape analyses at $10 \mathrm{~m}$ based on the Sentinel-2 imagery by down sampling coarser resolution image bands using a smoothing filter to match the resolution of the visible and near-infrared bands.

We built training and testing datasets of labeled point locations through manually examining NAIP imagery (2017) in combination with summarized Sentinel-2 image stacks to ensure selected points were not in an incorrect pixel due to geographic offsets of the two datasets. The non-tree category was an all-inclusive "other" category which, for example, included training points representing bare ground, herbaceous cover, and roads. All training and testing points were located inside of a $1 \mathrm{~km}$ buffered area of reference landscape and wildfire perimeters. A total of 450 training points were chosen, with approximately equal quantities for each category ( 130 points) other than water (59 points).

The resulting canopy cover classification had an accuracy of $99.7 \%$ based on out-of-bag sampling, or compared to the training labels, from the random forest model creation. A manual accuracy assessment was conducted using 250 randomly sampled points generated within 1 kilometer of reference landscapes and managed wildfire perimeters. Overall accuracy was less than the random forest out-of-bag estimate, but still high at 93\%. Both user's (errors of commission) and producer's accuracy (errors of omission) are listed in Table 1. Mean Users accuracy was $91 \%$ while mean producer's accuracy was $92 \%$.

Table 2

Accuracy assessment of classification outputs using randomly sampled validation points $(\mathrm{n}=250)$ located inside and within $1 \mathrm{~km}$ of the reference and managed wildfire landscapes included in the study. User's accuracies (right side column), producer's accuracies (bottom row) and overall accuracy (bottom-right) was high. Lower accuracies associated with deciduous cover likely results from understory greenness obfuscating the signal.

\begin{tabular}{|c|c|c|c|c|c|c|}
\hline & & \multicolumn{5}{|c|}{ Manual Classification } \\
\hline & & $\begin{array}{l}\text { Evergreen } \\
\text { cover }\end{array}$ & $\begin{array}{l}\text { Deciduous } \\
\text { cover }\end{array}$ & $\begin{array}{l}\text { Non-forest } \\
\text { cover }\end{array}$ & Total & \\
\hline \multirow[t]{5}{*}{$\begin{array}{l}\text { Random Forest } \\
\text { Classification }\end{array}$} & $\begin{array}{l}\text { Evergreen } \\
\text { cover }\end{array}$ & 98 & 0 & 3 & 101 & 0.97 \\
\hline & $\begin{array}{l}\text { Deciduous } \\
\text { cover }\end{array}$ & 0 & 33 & 7 & 40 & 0.825 \\
\hline & $\begin{array}{l}\text { Non-forest } \\
\text { cover }\end{array}$ & 3 & 5 & 101 & 109 & 0.927 \\
\hline & Total & 101 & 38 & 111 & 232 & \\
\hline & & 0.97 & 0.868 & 0.91 & & 0.928 \\
\hline
\end{tabular}

\subsection{Sampling along a gradient of landscape extents}

From our classified map, we calculated landscape metrics along a gradient of subsampled extents randomly generated within the reference and wildfire landscape perimeters. This approach allowed us to move beyond the traditional dependency on plot-based comparisons and undertake a more wholistic assessment of each landscape. As ponderosa pine was the dominant component of the landscape, and the cover type forest managers are interested in manipulating, we eliminated all other cover classification types before calculating metrics (Fig. 2). 
While we calculated a total of 55 class-level landscape metrics using the R package landscapemetrics (ver 1.4; Hesselbarth et al. 2019), we chose to focus on twelve metrics which encompassing a range of relevance to land management. Metrics analyzed were patch area and edge, core area, and several shape and aggregation metrics (see Table 1). A complete list of class-level landscape metrics and corresponding summaries for al focal landscapes (55 metrics) are included in Appendix B.

Table 3

List of landscape metrics considered for each of four patch-level metric classes and associated definition. For further details, see McGarigal and others (2012). Metric abbreviations are provided for consistency with existing landscape metric calculation software.

\begin{tabular}{|c|c|c|}
\hline $\begin{array}{l}\text { Metric } \\
\text { Class }\end{array}$ & Landscape metric & Definition \\
\hline \multirow{3}{*}{$\begin{array}{l}\text { Area and } \\
\text { Edge } \\
\text { Metrics }\end{array}$} & $\begin{array}{l}\text { Proportion of } \\
\text { landscape (PLAND) }\end{array}$ & Total proportion of extent covered by individual patches \\
\hline & $\begin{array}{l}\text { Patch area (mean, } \\
\text { st.dev) (AREA) }\end{array}$ & Summary of areas of individual patches within extent \\
\hline & Edge density (ED) & Quantity of patch edge relative to total area \\
\hline \multirow[t]{2}{*}{$\begin{array}{l}\text { Core Area } \\
\text { Metrics }\end{array}$} & $\begin{array}{l}\text { Core area } \\
\text { proportion of } \\
\text { landscape } \\
\text { (CPLAND) }\end{array}$ & Total proportion of extent covered by patch core area \\
\hline & $\begin{array}{l}\text { Core area index } \\
\text { (mean, st.dev) (CAI) }\end{array}$ & $\begin{array}{l}\text { CAl equals the patch core area }(\mathrm{m} 2) \text { divided by total patch area }(\mathrm{m} 2) \text {, } \\
\text { multiplied by } 100\end{array}$ \\
\hline $\begin{array}{l}\text { Shape } \\
\text { Metrics }\end{array}$ & $\begin{array}{l}\text { Shape index (mean, } \\
\text { st.dev) (SHAPE) }\end{array}$ & $\begin{array}{l}\text { The patch perimeter divided by the minimum perimeter possible for a } \\
\text { maximally compact patch (a square) of the same area. }\end{array}$ \\
\hline \multirow{3}{*}{$\begin{array}{l}\text { Aggregation } \\
\text { Metrics }\end{array}$} & Patch density (PD) & The number of patches relative to the total extent area. \\
\hline & $\begin{array}{l}\text { Normalized } \\
\text { landscape shape } \\
\text { index (nLSI) }\end{array}$ & $\begin{array}{l}\mathrm{nLSI} \text { is the total perimeter minus the minimum length of perimeter } \\
\text { possible for a maximally aggregated patch divided by the differenc of } \\
\text { those perimeters. }\end{array}$ \\
\hline & $\begin{array}{l}\text { Division index } \\
\text { (DIVISION) }\end{array}$ & $\begin{array}{l}\text { DIVISION equals } 1 \text { minus the sum of patch area }(\mathrm{m} 2) \text { divided by total } \\
\text { landscape area (m2), squared. }\end{array}$ \\
\hline
\end{tabular}

For each landscape extent from that of restoration sites ( $15 \mathrm{ha})$ to the largest managed wildfire extent $(\sim 15,000$ ha), we calculated all class-level landscape metrics. For the purposes of this research, we specifically present the set of landscape metrics which are directly applicable to landscape-scale forest management. We compared restoration sites to larger reference landscapes by randomly sampling 15 ha extents from within the reference landscape boundary to create a distribution of metrics at that same extent (15 ha). In the same way, we compared reference landscapes to managed wildfires among intervals of landscape extents by subsampling both within reference landscapes and managed wildfire boundaries and comparing the resulting distribution of landscape metrics. In this way, comparisons were made at each of those extents so as to avoid metric comparisons sensitive to extent (Wasserman et al. 2019). The maximum extent for comparison was approximately 800 ha, which was determined by the maximum size of available reference landscapes within the study area. We generated subsampled extents by randomly generating point locations within an inward-buffered landscape and buffering those points by the appropriate radius to achieve the desired extent which was then clipped by the landscape boundary (Fig. 2). The size of the inward buffer is a function of the radius of the desired subsample extent. The number of points generated is a 
function of the desired subsample extent area and the total area of the landscape. Resulting extent polygons were then filtered by removing buffered polygons whose centroid fell within a threshold number of resulting polygons (> $=5 \%$ of the total subsampled extents within the landscape) to promote the independence of the metrics calculated within a given landscape. As a final check, subsampled extents were removed if they were less than $75 \%$ of the target landscape extent area.

\subsection{Comparisons of landscape metrics}

Our analysis resulted in three general strata of landscape metrics: 1) inclusion of restoration sites at approximately 15 ha extent, 2) comparisons to reference landscapes up to approximately 800 ha extent, and 3) values only resulting from large wildfires up to approximately 15,000 ha extent (Fig. 2). Managed wildfires varied in size, from 452 ha to 14,529 ha while reference landscapes were smaller overall, ranging from 8 to 800 ha (Table 1). We only compared metrics calculated at similar extents, for each extent considered. Comparisons of metrics drawn from different landscape types were made using the Kolmogorov-Smirnov test (Marsaglia et al. 2003) in addition to the Mann-Whitney test (Sijtsma and Emons 2010). For both tests, significance was determined by an alpha value yet smaller than that of the appropriate Bonferroni correction $(a=0.01)$. The two-sample Kolmogorov-Smirnov test is a nonparametric test of how similar the shapes are for two continuous distributions are through a comparison of the empirical distribution function and the cumulative distribution function of the two samples, respectively (Marsaglia et al. 2003). The Mann-Whitney test is also a nonparametric rank sum test which examines the probability than any single sample is drawn from differing distributions (Sijtsma and Emons 2010).

\subsection{Determining metric importance across scale using random forest classifiers}

Finally, to understand which landscape metrics were the most important in discriminating reference and managed wildfire landscapes and how those differences changed with scale, we implemented a series of random forest classification models and retrieved variable importance, model accuracy, and sample sizes for each model $(\mathrm{N}=11)$. Random forest models were built using the 12 landscape metrics as predictors of landscape type (managed vs. reference). Models were built using 10,000 trees and assessing half of the landscape metrics at each tree node and individual landscape metric importance was assessed using a permutation approach within the random forest model. Variable importance values in combination with model accuracy were used to infer how individual landscape metrics are more or less differentiable across the scale gradient applicable to both reference and managed wildfire landscapes. Kendall rank correlation coefficients among the variables are included as an Appendix (Appendix C).

\section{Results}

\subsection{Comparison of small restoration sites to reference landscapes}

We initially compared landscape metrics among restored (15 ha) and reference landscapes (< 800 ha) as separate groups. However, testing showed that restored and reference landscapes were not statistically different from one another at our smallest landscape extent (Fig. 3). Because our analysis showed that these sites were consistent with functional landscapes when randomly subsampled at a similar extent ( $15 \mathrm{ha}$ ) from both Kolmogorov-Smirnov and Mann-Whitney test results we collapsed these categories into the singular 'reference' landscape category for further analysis. Of the metrics we examined, only edge density displayed significant differences (Fig. 3).

\subsection{Comparisons of landscape metrics among extents}


Similarities among restoration and reference landscape metrics justified combining them into a single "reference" class (see Sect. 2.4). Most landscape metrics were significantly different between reference and wildfire landscapes across the gradient of all extents tested (Fig. 4). The entirety of landscape metric values (55 metrics) are included as an Appendix (B). Among most landscape metrics we focused on, the distribution of metric values was significantly different according to both statistical tests and differences tended to increase as sampled extent increased. Of particular note were proportion of the landscape, (i.e., canopy cover), mean and standard deviation of canopy patch area, all three aggregation metrics, and the standard deviation of the shape index (Fig. 4). Median canopy cover in managed landscapes decreased with scale from 70.5\% (15-ha extent) to 60.8\% (840-ha extent) and continued to less than $50 \%$ at the largest wildland fire extent (15,000-ha). Similarly, canopy cover on reference landscapes decreased from $48.8 \%$ (15-ha) to $28.8 \%$ (840-ha). Differences in canopy cover between landscapes were statistically significant across all extents tested. Median patch area similarly decreased with scale, from $2.17 \pm 3.32$ ha (15-ha extent) to $1.5 \pm 22.4$ ha (840-ha extent) among managed landscapes and from $0.52 \pm 1.45$ ha (15-ha extent) to 0.24 \pm 1.78 ha (840-ha extent) among reference landscapes. The opposite relationship was true for patch density, which increased from $33.2 \mathrm{ha}^{-1}$ (15-ha extent) to $40.9 \mathrm{ha}^{-1}$ (840-ha extent) among managed landscapes and from 84.1 $\mathrm{ha}^{-1}$ (15-ha extent) to $122.2 \mathrm{ha}^{-1}$ (840-ha extent) among reference landscapes.

Of the remaining landscape metrics, the distribution of landscape metric values among reference and managed wildfire sampled extents were significantly different among smaller landscape extent comparisons but became nonsignificantly different from one another as sampled landscape extent increased according to both comparison tests (Fig. 4). However, the majority of metric distributions were significantly different according to the KolmogorovSmirnov test. The notable exception was edge density, for which both tests were not significant at any sampled extent but differed significantly according to the Kolmogorov-Smirnov test for sampled extents of 240 ha and smaller (Fig. 4). While there was no comparison for managed wildfire extents greater than 840 ha, among the majority of landscape metrics the trend established among smaller extents continued through the largest extent of 15,000 ha, with metrics tending smaller or larger in accordance with values extracted from smaller sampled extents (Fig. 4).

\subsection{Landscape metric importance across scale}

Overall, relative importance of the twelve landscape metrics for distinguishing between managed wildfires and reference sites decline with increasing landscape extent with greater importance among scales less than 240 ha (Fig. 5A). Despite this, model accuracy increased to nearly $100 \%$ with increasing sampled extent, increasingly rapidly up to 240 ha (Fig. 5B-C). In other words, as landscape extent increases, our resulting models were better able to distinguish landscape type (reference vs. managed) given less data and increasingly similar variable importance among predictors. An inflection in predictive accuracy appears to occur at the 240-ha scale (Fig. 5).

Area and aggregation metrics were consistently the most important landscape metrics for discriminating between landscape types across all scales examined. Specifically, proportion of the landscape, mean patch area and the normalized landscape shape index were the most important among landscape extents smaller than 240 ha (Fig. 5). Among these intermediary scales (up to $240 \mathrm{ha}$ ), we observed a shift in which variables were most important from proportion of landscape and the normalized landscape shape index to patch area and patch density. Patch area and division index are the most important landscape metrics at the largest extent (840 ha). Shape metrics were consistently less important among all scales while edge density was the least important metric at all extents greater than 240 ha (Fig. 5). 


\section{Discussion}

While we expected to see differences between reference and managed wildfire landscape patterns, our comparison at multiple scales shows that pattern and structure differences are not created equal along that scale gradient. Differences are relatively minor at small scales, as there tends to be a high degree of variability at these small scales, which coincide with traditional plot-based measurements. Differences tend to become more significant with increasing scale and the metrics defining those differences change in their importance as we move to landscape scales. While we initially explored a large suite of landscape metrics, we concentrated on twelve common metrics which easily translated to forest management and silvicultural prescriptions in particular (Reynolds et al. 2013; Churchill et al. 2013; Rodman et al. 2016), were parsimonious in their description of landscape pattern (Cushman et al. 2008), and were useful in evaluation of restoration treatment success (Dickinson et al. 2016; Ziegler et al. 2017; Huffman et al. 2017). Our approach to assessing differences across scale allowed us to examine those outcomes and provided some insight into the scales at which management would be necessary to address particular ecological processes and functions (Kerr and Ostrovsky 2003; Uuemaa et al. 2013; Wan et al. 2020) and could serve to help outline future restoration planning efforts (Churchill et al. 2013; Dickinson et al. 2016; Cannon et al. 2020; Wan et al. 2020).

\subsection{Reference landscape patterns}

Landscape patterns at restored sites at the 15-ha scale were entirely consistent with those of intact ponderosa pine forest landscapes that had not experienced notable impacts of late 19th century livestock grazing and fire exclusion. Because of this, we were able to combine restored and functioning landscapes into a single reference class for the remainder of the analysis. While Mount Trumbull stands out as a unique landscape in terms of extent treated, ambitious efforts are presently underway to apply restoration treatments across millions of hectares throughout the Southwest (Schultz et al. 2012). Similarity between restoration sites and intact landscapes suggests that restoration treatments, as implemented using the ERG method (see Tuten et al. 2015), have measurably promoted forest structural conditions consistent with reference landscapes, complementing many previous studies relying on plotbased measurements of forest structure (Mast et al. 1999; Fulé et al. 2002; Waltz et al. 2003; Roccaforte et al. 2010, 2015; Tuten et al. 2015). Canopy proportion of the landscape, mean patch size and patch density were very similar among restored and functioning landscapes, although restored landscapes tended to be comprised of smaller and more numerous tree patches. Edge density was the only metric that differed significantly between restored and intact landscapes, potentially resulting from mechanical treatments which targeted the restoration of functioning conditions through tree spacing and patch size guidelines, but failed to provide the full spatial complexity across scales that might stem from a frequent fire regime (Hargis et al. 1998; Mclver et al. 2013).

\subsection{Comparisons to managed wildland fires}

In general, landscape metrics derived from wildland fires managed for resource benefit were significantly different from those of reference sites across the gradient of landscape extents we tested. Managed wildfires exhibited greater canopy cover, larger patch size and corresponding lower patch density, and divergent shape complexity compared with reference sites. Taken together, these differences reflect the denser forest conditions typical of fireexcluded ponderosa pine forests that continue to predominate at the wildfire sites. In turn, dense forest conditions and larger patches of contiguous canopy on the managed wildfire sites reflect low burn severity and a limited number of fire entries, conclusions that parallel those drawn in previous studies examining managed wildfires in the Southwest (Huffman et al. 2017, 2018). In fact, only one fire we examined had greater than $10 \%$ of its area classified as moderate burn severity, and only two fires had more than $1 \%$ of total area classified as high severity. Such 
homogenous and dense conditions are common in southwestern ponderosa pine forests where surface fire has been excluded for decades and thinning activities have not yet occurred (Covington et al. 1997). Interestingly, edge density was similar among all treatment types, perhaps resulting from larger patches having a similar amount of patch edge to that observed for smaller, yet more complex, canopy patches (see Cushman et al. 2008) and perhaps suggesting edge density is not a good metric for active forest management.

Larger contiguous patches of forest canopy within managed wildfires suggest that numerous restoration objectives, such as reduction of canopy fuels and crown fire hazard, promotion of understory plant production and diversity through decreased resource competition from overstory trees, and increases in habitat suitability for wildlife species associated with forest edges, have not been effectively met (Covington et al. 1997, Laughlin et al. 2008, Fulé et al. 2012, Reynolds et al. 2013). Homogeneity of forest canopy and lack of structural complexity also increase vulnerability of ecosystems to landscape-scale disturbances such as stand-replacing wildfire, bark beetle attacks, and density-dependent or drought induced mortality (Covington et al. 1997, Agee and Skinner 2005; Kolb et al. 2007; McWethy et al. 2019). Although, interconnected tree crowns and greater canopy cover are important for some wildlife species, such as the tassel-eared squirrel (Sciurus aberti), Mexican spotted-owl (Strix occidentalis lucida), and northern goshawk (Accipiter gentilis)(Ganey et al. 1999; Prather et al. 2006; Loberger et al. 2011; Tuten et al. 2015; Bagdon et al. 2016), severe loss of habitat due to stand-replacing fire is of high concern to forest managers. Over time, repeated fire occurrence, especially if allowed to burn at severity levels that reduce tree density, can increase heterogeneity by breaking up larger forest stands and creating discontinuous, smaller tree patches as well as moderating understory tree growth into the overstory (Hargis et al. 1998; Covington et al. 2001; Hunter et al. 2011; Reynolds et al. 2013; Huffman et al. 2018; Kane et al. 2019). Thus, to meet objectives associated with ecological restoration, repeated low- to moderate-severity wildfires are necessary to disrupt continuous canopy structure typical of fire-excluded forests and restore spatial patterns more consistent with the natural range of variation (Allen et al. 2002; Reynolds et al. 2013, Huffman et al. 2017). If fires are consistently managed for minimal effects and low burn severity, time required to incrementally produce fine-grain structural patterns may be beyond typical planning horizons for public land managers (Collins et al. 2009; van Wagtendonk et al. 2012; Huffman et al. 2018; Yocom et al. 2019). Generally, fragmentation, which in fire-excluded ponderosa pine forests is likely to increase heterogeneity, has been shown to be linearly related to the proportion of the landscape disturbed (Hargis et al. 1998; McGarigal et al. 2012). First-entry wildfires can reestablish canopy structure consistent with reference landscapes if allowed to burn at some moderate severities (Huffman et al. 2018; Kane et al. 2019), but this is often not preferable when natural resource and other values are perceived to be at high risk (North et al. 2015).

Landscape patterns in southwestern ponderosa pine forests are a product of the dominant disturbance process: low severity, small-scale wildfire (Allen et al. 2002; Veblen 2003; Reynolds et al. 2013). In a functioning forest, such as our reference landscapes, this disturbance is sufficient to maintain low tree density and discontinuous canopy, but fails to do so once the age of dominant trees develop fire resistance and high tree densities promote canopy transmission of fire with catastrophic results (Reynolds et al. 2013; Tarancón et al. 2014; Bottero et al. 2017; Ritter et al. 2020). Sustained small-scale wildfire will promote heterogeneity primarily at small scales, but not over large landscape scales, wherein the mosaic of burned areas becomes homogenous (Wasserman et al. 2019). Our results showed this pattern of greater heterogeneity transitioning to greater homogeneity among both reference and wildfire landscapes decreased with scale. While the range of landscape metric values became increasingly constrained with increasing extent, reference landscape metrics were generally more constrained than their managed wildfire counterpart, suggesting that heterogeneity may not have been a key element at all scales for reference landscapes. It is possible that we were not able to examine landscapes large enough to see an eventual increase in heterogeneity at larger landscape extents, exemplifying a key constraint to our study, the lack of large reference landscapes.

Page 12/26 
Variability in patch area was the only metric examined which exhibited the opposite pattern of increased heterogeneity with increasing scale, and this was only among managed wildfire landscapes. This was likely due to increasingly large patches being included in summaries as extents became larger; the same was not true for reference landscapes.

\subsection{The effect of scale on metrics}

Consistent with Random forest models surprising results in that we found rapidly increasing model accuracy while sample size decreased, coupled with an overall decline in variable importance (Cutler et al. 2007). These results suggest that the managed and reference landscapes became increasingly different with scale, suggesting that landscape types grew progressively more distinct with scale. These results coupled with increased homogeneity of landscape metrics with landscape extent suggest that these landscape types homogenize with scale in different ways, which is evident in the distinct trends of each landscape metric across sampled extents. An inflection in both model accuracy and variable importance was apparent at the 240-ha landscape extent, corresponding to the accepted definition of mid-scale landscape structure in these dry ponderosa forests (Reynolds et al. 2013). The inflection suggested that landscapes were more variable among scales up to 240 ha, likely the result of fine-scale processes and management (Kalies and Yocom Kent 2016; Ritter et al. 2020), become increasingly homogeneous among larger scales, and still exhibit diverging structural patterns among landscape types.

Landscape metrics scaled predictably across the gradient of extents we examined, consistent with a type I scaling relationship (Wu and Hobbs 2002; Wu 2004). We expect this behavior in ponderosa forests due to the dominant disturbance regime of small-scale wildfire, leading to increased homogeneity with scale (Wasserman et al. 2019). We see evidence for this as the range of most metric values became increasingly constrained as the scale of landscape extents grew, while tending towards divergent metric values for each landscape type. Understanding the behavior of ponderosa forest landscape pattern across scales is necessary for scale-dependent ecological function and management objectives (Turner and Gardner 2015), including wildland fire behavior (Povak et al. 2018), habitat suitability (Timm et al. 2016; McGarigal et al. 2016; Wan et al. 2020), forest health and ecohydrology (Stevens 2017), and climate mitigation and carbon sequestration (McCauley et al. 2019). Shape metrics were consistently unimportant in our models, suggesting area and aggregation metrics are more important for assessing treatment effectiveness and guiding future restoration plans.

\subsection{Methods and limitations}

Our simple classification of ponderosa pine forest cover had high accuracy according to both out-of-bag model training and an independent comparison of manual classifications. This was in part due to the relatively simple classification scheme as well as the inclusion of a seasonal component, which effectively discriminated between evergreen and deciduous vegetation. While the Sentinel-2 imagery can fail to detect single trees and small tree groups due to the size of object of interest relative to the $10-\mathrm{m}$ resolution of the imagery, the resolution is sufficient to detect mature individual trees or tree groups of ponderosa pine due to their average size (e.g. we expect a mature ponderosa to have a radius in the range of 6 meters) and thus appropriate for examining forest structure over large landscapes (Wasserman et al. 2019; Grabska et al. 2020; Schumacher et al. 2020). See Wasserman and others (2019) for a comparison of landscape metrics resulting from a gradient of data resolution. Higher resolution data, such as lidar or airborne imagery, may more accurately capture smaller patch sizes; however, expense and availability of these types of datasets for regional landscapes is limited (Buyantuyev and Wu 2007; Wasserman et al. 2019). We suggest that methods used in our study have broad applicability for assessment and post-treatment monitoring of ponderosa forest structure in the Southwest (see also Botequilha Leitão and Ahern 2002; de Almeida 
et al. 2020). However, further research is needed to understand metrics vary not only with extent, but also grain as interpretation of landscape structure and pattern can vary with grain size (Hargis et al. 1998; Buyantuyev and Wu 2007; Corry and Lafortezza 2007; Rutchey and Godin 2009; Šímová and Gdulová 2012; Wasserman et al. 2019; Wickham and Riitters 2019).

As previously described, we were limited by a lack of suitable reference landscapes to include for comparisons in our analysis largely due to the widespread effects of historical livestock grazing and fire exclusion in the Southwest region (Covington et al. 1997; Moore et al. 1999; Reynolds et al. 2013). With limited availability of reference landscapes, it becomes hard to account for variation stemming from abiotic factors, including soil parent material, elevation, topography, climate, and disturbance history variables (Puhlick et al. 2012; Larson and Churchill 2012; Reynolds et al. 2013; Rodman et al. 2017). However, all landscapes we examined, both reference and managed, are within the elevation band of ponderosa pine distribution and all would have been subject to the same disturbance events historically. We were also limited by the size of available reference landscapes. For example, our sampling extents from reference landscapes were limited to a maximum of approximately 800 ha, while managed wildfire landscapes included in our analysis were as large as 15,000 ha. This discrepancy presents a challenge for understanding reference landscapes of the Southwest at a range of scales and how those landscapes compare to contemporary landscape management. The paucity of potential reference landscapes confirms the urgent need for accelerated large-scale forest management (Stephens et al. 2016; Cannon et al. 2018), but also highlights the difficulties in managing for ecologically functioning, resilient forest landscapes under threat of climate change and competing land uses (Bradford and D'Amato 2012; Stanturf et al. 2014; Jacobs et al. 2015; Gleason et al. 2017; McCauley et al. 2019; Cannon et al. 2020). We hope to increase the geographic footprint of the study area in future research, but disparate landscapes necessitate accounting for increasingly large amounts of variability in both biotic and abiotic factors contributing to forest structure (Johnston et al. 2016; Rodman et al. 2017).

\section{Conclusion}

Overall, forest landscape patterns resulting from wildland fires managed for resource benefit do not correspond to reference landscape pattern at analogous scales. While larger restored and functioning landscapes are needed in the region, the reference landscapes we identified provide for comparisons up to the scale of multiple forest stands, a scale at which we found that managed wildfire landscapes differed the most from reference. Our analysis showed that managed wildfires did not achieve patterns similar to those of intact and restored landscapes. While more work is needed to include a greater geographic scope and variability in reference and managed wildfire landscapes, this analysis agrees with recent studies showing that wildland fires managed for resource benefit generally have not achieved met restoration goals related to forest structure and ecological function in large extents of low burn severity. In our study, the finding that greater canopy cover was often coupled with fewer, yet larger landscape patches was likely a result of low burn severity and minimal effects of wildfire on forest structure. Differences between wildfire and reference landscapes became more pronounced at larger scales as patterns became increasingly homogenous, most likely due to a lack of disturbance events, fire or otherwise, which allow large, contiguous forest canopies to persist. Low severity disturbance can change forest structure over time, but the timeline for significant change is very long. Mimicking forest function through repeated, moderate severity fire or mechanical treatment is needed to move landscape structure towards that of reference conditions, but simply does not exist in any large quantity across the region. Understanding the scale-dependent relationships of management activities and ecological function with landscape patterns is necessary to improve management outcomes and fire policy and greater emphasis on forest structure across scales is needed to provide for resilient, healthy ponderosa forests.

Page $14 / 26$ 


\section{Declarations}

\section{Acknowledgements}

We thank staff and students of the Ecological Restoration Institute at Northern Arizona University for field data collection, logistical support, and providing ideas and considerations while formulating the study and manuscript. We also thank our colleagues with the Coconino and Kaibab National Forests for their continued support, including assistance with research coordination. Northern Arizona University is an equal opportunity provider.

\section{Funding}

This research was supported by a grant from the USDA Forest Service.

\section{Availability of data and material}

All data used for the analysis is available through Google Earth Engine.

\section{Authors' contributions}

All authors contributed to the study conception and design. Material preparation, data collection and analysis were performed by Jonathon Donager. The first draft of the manuscript was written by Jonathon Donager and all authors commented on previous versions of the manuscript. All authors read and approved the final manuscript.

equal opportunity provider.

\section{References}

Ager AA, Evers CR, Day MA, et al (2017) Network analysis of wildfire transmission and implications for risk governance. PLoS One 12:e0172867. https://doi.org/10.1371/journal.pone.0172867

Allen CD, Savage M, Falk DA, et al (2002) Ecological Restoration of Southwestern Ponderosa Pine Ecosystems: A Broad Perspective. Ecol Appl 12:1418. https://doi.org/10.2307/3099981

Bagdon BA, Huang C-HH, Dewhurst S (2016) Managing for ecosystem services in northern Arizona ponderosa pine forests using a novel simulation-to-optimization methodology. Ecol Modell 324:11-27.

https://doi.org/10.1016/j.ecolmodel.2015.12.012

Barros AMG, Ager AA, Day MA, et al (2018) Wildfires managed for restoration enhance ecological resilience. Ecosphere 9:e02161. https://doi.org/10.1002/ecs2.2161

Botequilha Leitão A, Ahern J (2002) Applying landscape ecological concepts and metrics in sustainable landscape planning. Landsc Urban Plan 59:65-93. https://doi.org/10.1016/S0169-2046(02)00005-1

Bottero A, D'Amato AW, Palik BJ, et al (2017) Density-dependent vulnerability of forest ecosystems to drought. J Appl Ecol 54:1605-1614. https://doi.org/10.1111/1365-2664.12847

Bradford JB, D'Amato AW (2012) Recognizing trade-offs in multi-objective land management. Front Ecol Environ 10:210-216. https://doi.org/10.1890/110031 
Buyantuyev A, Wu J (2007) Effects of thematic resolution on landscape pattern analysis. Landsc Ecol 22:7-13. https://doi.org/10.1007/s10980-006-9010-5

Cannon JB, Barrett KJ, Gannon BM, et al (2018) Collaborative restoration effects on forest structure in ponderosa pine-dominated forests of Colorado. For Ecol Manage 424:191-204. https://doi.org/10.1016/j.foreco.2018.04.026

Cannon JB, Gannon BM, Feinstein JA, et al (2020) Simulating spatial complexity in dry conifer forest restoration: implications for conservation prioritization and scenario evaluation. Landsc Ecol 8:1-19.

https://doi.org/10.1007/s10980-020-01111-8

Churchill DJ, Larson AJ, Dahlgreen MC, et al (2013) Restoring forest resilience: From reference spatial patterns to silvicultural prescriptions and monitoring. For Ecol Manage 291:442-457.

https://doi.org/10.1016/j.foreco.2012.11.007

Cocke AE, Fulé PZ, Crouse JE (2005) Comparison of burn severity assessments using Differenced Normalized Burn Ratio and ground data. Int J Wildl Fire 14:189-198. https://doi.org/10.1071/WF04010

Collins BM, Everett RG, Stephens SL, et al (2011) Impacts of fire exclusion and recent managed fire on forest structure in old growth Sierra Nevada mixed-conifer forests. Ecosphere 2:1-14. https://doi.org/10.1890/ES1100026.1

Corry RC, Lafortezza R (2007) Sensitivity of landscape measurements to changing grain size for fine-scale design and management. Landsc Ecol Eng 3:47-53. https://doi.org/10.1007/s11355-006-0015-7

Covington WW, Fulé PZ, Hart SC, Weaver RP (2001) Modeling ecological restoration effects on ponderosa pine forest structure. Restor Ecol 9:421-431. https://doi.org/10.1046/j.1526-100X.2001.94011.x

Covington WW, Fulé PZ, Moore MM, et al (1997) Restoring ecosystem health in ponderosa pine forests of the southwest. J For 95:23-29. https://doi.org/10.1093/jof/95.4.23

Cushman SA, McGarigal K, Neel MC (2008) Parsimony in landscape metrics: Strength, universality, and consistency. Ecol Indic 8:691-703. https://doi.org/10.1016/j.ecolind.2007.12.002

Cutler DR, Edwards TC, Beard KH, et al (2007) Random forests for classification in ecology. Ecology 88:2783-2792. https://doi.org/10.1890/07-0539.1

de Almeida DRA, Stark SC, Valbuena R, et al (2020) A new era in forest restoration monitoring. Restor Ecol 28:8-11. https://doi.org/10.1111/rec. 13067

Dickinson Y, Pelz K, Giles E, Howie J (2016) Have we been successful? Monitoring horizontal forest complexity for forest restoration projects. Restor Ecol 24:8-17. https://doi.org/10.1111/rec.12291

Eidenshink J, Schwind B, Brewer K, et al (2007) A Project for Monitoring Trends in Burn Severity. Fire Ecol 3:3-21. https://doi.org/10.4996/fireecology.0301003

Fitch RA, Kim YS, Waltz AEM, Crouse JE (2018) Changes in potential wildland fire suppression costs due to restoration treatments in Northern Arizona Ponderosa pine forests. For Policy Econ 87:101-114.

https://doi.org/10.1016/j.forpol.2017.11.006

Page $16 / 26$ 
Fulé PZ, Covington WW, Smith HB, et al (2002) Comparing ecological restoration alternatives: Grand Canyon, Arizona. For Ecol Manage 170:19-41. https://doi.org/10.1016/S0378-1127(01)00759-9

Fulé PZ, Crouse JE, Cocke AE, et al (2004) Changes in canopy fuels and potential fire behavior 1880-2040: Grand Canyon, Arizona. Ecol Modell 175:231-248. https://doi.org/10.1016/j.ecolmodel.2003.10.023

Ganey JL, Block WM, Jenness JS, Wilson RA (1999) Mexican spotted owl home range and habitat use in pine-oak forest: Implications for forest management. For Sci 45:127-135. https://doi.org/10.1093/forestscience/45.1.127

Gleason KE, Bradford JB, Bottero A, et al (2017) Competition amplifies drought stress in forests across broad climatic and compositional gradients. Ecosphere 8:. https://doi.org/10.1002/ecs2.1849

Gorelick N, Hancher M, Dixon M, et al (2017) Google Earth Engine: Planetary-scale geospatial analysis for everyone. Remote Sens Environ 202:18-27. https://doi.org/10.1016/j.rse.2017.06.031

Grabska E, Frantz D, Ostapowicz K (2020) Evaluation of machine learning algorithms for forest stand species mapping using Sentinel-2 imagery and environmental data in the Polish Carpathians. Remote Sens Environ 251:112103. https://doi.org/10.1016/j.rse.2020.112103

Hargis CD, Bissonette JA, David JL (1998) The behavior of landscape metrics commonly used in the study of habitat fragmentation. Landsc Ecol 13:167-186. https://doi.org/10.1023/A:1007965018633

Hengl T, De Jesus JM, Heuvelink GBM, et al (2017) SoilGrids250m: Global gridded soil information based on machine learning. PLoS One 12:e0169748. https://doi.org/10.1371/journal.pone.0169748

Hesselbarth MHK, Sciaini M, With KA, et al (2019) landscapemetrics: an open-source R tool to calculate landscape metrics. Ecography (Cop) 42:1648-1657. https://doi.org/10.1111/ecog.04617

Hjerpe E, Abrams J, Becker DR (2009) Socioeconomic barriers and the role of biomass utilization in southwestern ponderosa pine restoration. Ecol. Restor. 27:169-177

Huffman DW, Crouse JE, Sánchez Meador AJ, et al (2018) Restoration benefits of re-entry with resource objective wildfire on a ponderosa pine landscape in northern Arizona, USA. For Ecol Manage 408:16-24.

https://doi.org/10.1016/j.foreco.2017.10.032

Huffman DW, Roccaforte JP, Springer JD, Crouse JE (2020) Restoration applications of resource objective wildfires in western US forests: a status of knowledge review. Fire Ecol. 16:1-13

Huffman DW, Sánchez Meador AJ, Stoddard MT, et al (2017) Efficacy of resource objective wildfires for restoration of ponderosa pine (Pinus ponderosa) forests in northern Arizona. For Ecol Manage 389:395-403.

https://doi.org/10.1016/j.foreco.2016.12.036

Hunter ME, Iniguez JM, Lentile LB (2011) Short- and long-term effects on fuels, forest structure, and wildfire potential from prescribed fire and resource benefit fire in southwestern forests, USA. Fire Ecol 7:108-121. https://doi.org/10.4996/fireecology.0703108

Jacobs DF, Oliet JA, Aronson J, et al (2015) Restoring forests: What constitutes success in the twenty-first century? New For. 46:601-614 
Johnston JD, Bailey JD, Dunn CJ (2016) Influence of fire disturbance and biophysical heterogeneity on presettlement ponderosa pine and mixed conifer forests. Ecosphere 7:. https://doi.org/10.1002/ecs2.1581

Kalies EL, Yocom Kent LL (2016) Tamm Review: Are fuel treatments effective at achieving ecological and social objectives? A systematic review. For Ecol Manage 375:84-95. https://doi.org/10.1016/j.foreco.2016.05.021

Kane VR, Bartl-Geller BN, North MP, et al (2019) First-entry wildfires can create opening and tree clump patterns characteristic of resilient forests. For Ecol Manage 454:117659. https://doi.org/10.1016/j.foreco.2019.117659

Kerr JT, Ostrovsky M (2003) From space to species: Ecological applications for remote sensing. Trends Ecol Evol 18:299-305. https://doi.org/10.1016/S0169-5347(03)00071-5

Larson AJ, Churchill D (2012) Tree spatial patterns in fire-frequent forests of western North America, including mechanisms of pattern formation and implications for designing fuel reduction and restoration treatments. For Ecol Manage 267:74-92. https://doi.org/10.1016/j.foreco.2011.11.038

Li J, Roy DP (2017) A global analysis of Sentinel-2a, Sentinel-2b and Landsat-8 data revisit intervals and implications for terrestrial monitoring. Remote Sens 9:902. https://doi.org/10.3390/rs9090902

Loberger CD, Theimer TC, Rosenstock SS, Wightman CS (2011) Use of restoration-treated ponderosa pine forest by tassel-eared squirrels. J Mammal 92:1021-1027. https://doi.org/10.1644/10-MAMM-A-321.1

Lowry J, Ramsey RD, Thomas K, et al (2007) Mapping moderate-scale land-cover over very large geographic areas within a collaborative framework: A case study of the Southwest Regional Gap Analysis Project (SWReGAP). Remote Sens Environ 108:59-73. https://doi.org/10.1016/j.rse.2006.11.008

Lydersen JM, North MP, Knapp EE, Collins BM (2013) Quantifying spatial patterns of tree groups and gaps in mixedconifer forests: Reference conditions and long-term changes following fire suppression and logging. For Ecol Manage 304:370-382. https://doi.org/10.1016/j.foreco.2013.05.023

Marsaglia G, Tsang WW, Wang J (2003) Evaluating Kolmogorov's distribution. J Stat Softw 8:1-4. https://doi.org/10.18637/jss.v008.i18

Mast JN, Fulé PZ, Moore MM, et al (1999) Restoration of presettlement age structure of an Arizona ponderosa pine forest. Ecol Appl 9:228-239. https://doi.org/10.1890/1051-0761(1999)009[0228:ROPASO]2.0.CO;2

McCauley LA, Robles MD, Woolley T, et al (2019) Large-scale forest restoration stabilizes carbon under climate change in Southwest United States. Ecol Appl 29:e01979. https://doi.org/10.1002/eap.1979

McGarigal K, Cushman SA, Ene E (2012) FRAGSTATS v4: spatial pattern analysis program for categorical and continuous maps. In: Comput. Softw. Progr. Prod. by authors Univ. Massachusetts, Amherst. Available Follow. web site http//www. umass. edu/landeco/research/fragstats/fragstats. html.

McGarigal K, Wan HY, Zeller KA, et al (2016) Multi-scale habitat selection modeling: a review and outlook. Landsc Ecol 31:1161-1175. https://doi.org/10.1007/s10980-016-0374-x

Mclver JD, Stephens SL, Agee JK, et al (2013) Ecological effects of alternative fuel-reduction treatments: Highlights of the National Fire and Fire Surrogate study (FFS). Int. J. Wildl. Fire 22:63-82 
Moore MM, Covington WW, Fulé PZ (1999) Reference conditions and ecological restoration: A Southwestern ponderosa pine perspective. Ecol. Appl. 9:1266-1277

Moore MM, Huffman DW, Fulé PZ, et al (2004) Comparison of Historical and Contemporary Forest Structure and Composition on Permanent Plots in Southwestern Ponderosa Pine Forests. For Sci 50:162-176.

https://doi.org/10.1093/forestscience/50.2.162

MTBS (2017) MTBS Data Access: Fire Level Geospatial Data. In: Monit. Trends Burn Sev. Proj. (USDA For. Serv. Geol. Surv. http://mtbs.gov/direct-download. Accessed 1 Nov 2019

North M, Collins BM, Stephens S (2012) Using Fire to Increase the Scale, Benefits, and Future Maintenance of Fuels Treatments. J For 110:392-401. https://doi.org/10.5849/jof.12-021

North MP, Stephens SL, Collins BM, et al (2015) Reform forest fire management: Agency incentives undermine policy effectiveness. Science (80-. ). 349:1280-1281

Povak NA, Hessburg PF, Salter RB (2018) Evidence for scale-dependent topographic controls on wildfire spread. Ecosphere 9:e02443. https://doi.org/10.1002/ecs2.2443

Prather JW, Dodd NL, Dickson BG, et al (2006) Landscape Models to Predict the Influence of Forest Structure on Tassel-Eared Squirrel Populations. J Wildl Manage 70:723-731. https://doi.org/10.2193/0022-

541x(2006)70[723:Imtpti]2.0.co;2

PRISM Climate Group OSU http://prism.oregonstate.edu

Puhlick JJ, Laughlin DC, Moore MM (2012) Factors influencing ponderosa pine regeneration in the southwestern USA. For Ecol Manage 264:10-19. https://doi.org/10.1016/j.foreco.2011.10.002

Reynolds RT, Sánchez Meador AJ, Youtz JA, et al (2013) Restoring Composition and Structure in Southwestern Frequent-Fire Forests: A science-based framework for improving ecosystem resiliency. Gen Tech Rep RMRS-GTR-310 86

Ritter SM, Hoffman CM, Battaglia MA, et al (2020) Fine-scale fire patterns mediate forest structure in frequent-fire ecosystems. Ecosphere 11:e03177. https://doi.org/10.1002/ecs2.3177

Roccaforte JP, Fulé PZ, Covington WW (2010) Monitoring Landscape-Scale Ponderosa Pine Restoration Treatment Implementation and Effectiveness. Restor Ecol 18:820-833. https://doi.org/10.1111/j.1526-100X.2008.00508.x

Roccaforte JP, Huffman DW, Fulé PZ, et al (2015) Forest structure and fuels dynamics following ponderosa pine restoration treatments, White Mountains, Arizona, USA. For Ecol Manage 337:174-185.

https://doi.org/10.1016/j.foreco.2014.11.001

Rodman KC, Sánchez Meador AJ, Huffman DW, Waring KM (2016) Reference conditions and historical fine-scale spatial dynamics in a dry mixed-conifer forest, Arizona, USA. For Sci 62:268-280. https://doi.org/10.5849/forsci.15136

Rodman KC, Sánchez Meador AJ, Moore MM, Huffman DW (2017) Reference conditions are influenced by the physical template and vary by forest type: A synthesis of Pinus ponderosa-dominated sites in the southwestern United States. For Ecol Manage 404:316-329. https://doi.org/10.1016/j.foreco.2017.09.012 
Rutchey K, Godin J (2009) Determining an appropriate minimum mapping unit in vegetation mapping for ecosystem restoration: A case study from the Everglades, USA. Landsc Ecol 24:1351-1362. https://doi.org/10.1007/s10980$009-9387-z$

Sánchez Meador AJ, Moore MM, Bakker JD, Parysow PF (2009) 108 years of change in spatial pattern following selective harvest of a Pinus ponderosa stand in northern Arizona, USA. J Veg Sci 20:79-90. https://doi.org/10.1046/j.1365-2893.1999.00142.x-i1

Sánchez Meador AJ, Parysow PF, Moore MM (2011) A New Method for Delineating Tree Patches and Assessing Spatial Reference Conditions of Ponderosa Pine Forests in Northern Arizona. Restor Ecol 19:490-499. https://doi.org/10.1111/j.1526-100X.2010.00652.x

Schultz CA, Jedd T, Beam RD (2012) The Collaborative Forest Landscape Restoration Program: A History and Overview of the First Projects. J For 110:381-391. https://doi.org/10.5849/jof.11-082

Schumacher J, Hauglin M, Astrup R, Breidenbach J (2020) Mapping forest age using National Forest Inventory, airborne laser scanning, and Sentinel-2 data. For Ecosyst 7:. https://doi.org/10.1186/s40663-020-00274-9

Sijtsma K, Emons WHM (2010) Nonparametric statistical methods. In: International Encyclopedia of Education. John Wiley \& Sons, pp 347-353

Šímová P, Gdulová K (2012) Landscape indices behavior: A review of scale effects. Appl Geogr 34:385-394. https://doi.org/10.1016/j.apgeog.2012.01.003

Stanturf JA, Palik BJ, Dumroese RK (2014) Contemporary forest restoration: A review emphasizing function. For Ecol Manage 331:292-323. https://doi.org/10.1016/j.foreco.2014.07.029

Stephens SL, Collins BM, Biber E, Fulé PZ (2016) U.S. Federal fire and forest policy: Emphasizing resilience in dry forests. Ecosphere 7:1-19. https://doi.org/10.1002/ecs2.1584

Stevens JT (2017) Scale-dependent effects of post-fire canopy cover on snowpack depth in montane coniferous forests. Ecol Appl 27:1888-1900. https://doi.org/10.1002/eap.1575

Stevens JT, Collins BM, Miller JD, et al (2017) Changing spatial patterns of stand-replacing fire in California conifer forests. For Ecol Manage 406:28-36. https://doi.org/10.1016/j.foreco.2017.08.051

SWReGAP (2005) Southwest Regional GAP Analysis Project - Land Cover Descriptions. 250

Tarancón AA, Fulé PZ, Shive KL, et al (2014) Simulating post-wildfire forest trajectories under alternative climate and management scenarios. Ecol Appl 24:1626-1637. https://doi.org/10.1890/13-1787.1

Theobald DM, Harrison-Atlas D, Monahan WB, Albano CM (2015) Ecologically-relevant maps of landforms and physiographic diversity for climate adaptation planning. PLoS One 10:e0143619.

https://doi.org/10.1371/journal.pone.0143619

Timm BC, McGarigal K, Cushman SA, Ganey JL (2016) Multi-scale Mexican spotted owl (Strix occidentalis lucida) nest/roost habitat selection in Arizona and a comparison with single-scale modeling results. Landsc Ecol 31:12091225. https://doi.org/10.1007/s10980-016-0371-0 
Turner MG, Gardner RH (2015) Landscape ecology in theory and practice: Pattern and process, second edition. Springer New York

Tuten MC, Sánchez Meador A, Fulé PZ (2015) Ecological restoration and fine-scale forest structure regulation in southwestern ponderosa pine forests. For Ecol Manage 348:57-67. https://doi.org/10.1016/j.foreco.2015.03.032

Uuemaa E, Mander Ü, Marja R (2013) Trends in the use of landscape spatial metrics as landscape indicators: A review. Ecol Indic 28:100-106. https://doi.org/10.1016/j.ecolind.2012.07.018

Veblen TT (2003) Historic range of variability of mountain forest ecosystems: Concepts and applications. For Chron 79:223-226. https://doi.org/10.5558/tfc79223-2

Waltz AE, Fulé PZ, Covington WW, Moore MM (2003) Diversity in Ponderosa Pine Forest Structure Following Ecological Restoration Treatments. For Sci 49:885-900. https://doi.org/10.1093/forestscience/49.6.885

Wan HY, Cushman SA, Ganey JL (2020) The effect of scale in quantifying fire impacts on species habitats. Fire Ecol 16:1-15. https://doi.org/10.1186/s42408-020-0068-2

Wasserman TN, Sánchez Meador AJ, Waltz AEM (2019) Grain and extent considerations are integral for monitoring landscape-scale desired conditions in fire-adapted forests. Forests 10:1-21. https://doi.org/10.3390/f10060465

Weber KT, Yadav R (2020) Spatiotemporal Trends in Wildfires across the Western United States (1950-2019). Remote Sens 12:2959. https://doi.org/10.3390/rs12182959

Wickham J, Riitters KH (2019) Influence of high-resolution data on the assessment of forest fragmentation. Landsc Ecol 34:2169-2182. https://doi.org/10.1007/s10980-019-00820-z

Wright MN, Ziegler A (2017) Ranger: A fast implementation of random forests for high dimensional data in C++ and R. J Stat Softw 77:1-17. https://doi.org/10.18637/jss.v077.i01

Wu J (2004) Effects of changing scale on landscape pattern analysis: Scaling relations. Landsc Ecol 19:125-138. https://doi.org/10.1023/B:LAND.0000021711.40074.ae

Wu J, Hobbs R (2002) Key issues and research priorities in landscape ecology. Landsc Ecol 17:355-365

Wulder MA, Masek JG, Cohen WB, et al (2012) Opening the archive: How free data has enabled the science and monitoring promise of Landsat. Remote Sens Environ 122:2-10. https://doi.org/10.1016/j.rse.2012.01.010

Ziegler JP, Hoffman C, Battaglia M, Mell W (2017) Spatially explicit measurements of forest structure and fire behavior following restoration treatments in dry forests. For Ecol Manage 386:1-12.

https://doi.org/10.1016/j.foreco.2016.12.002

\section{Figures}



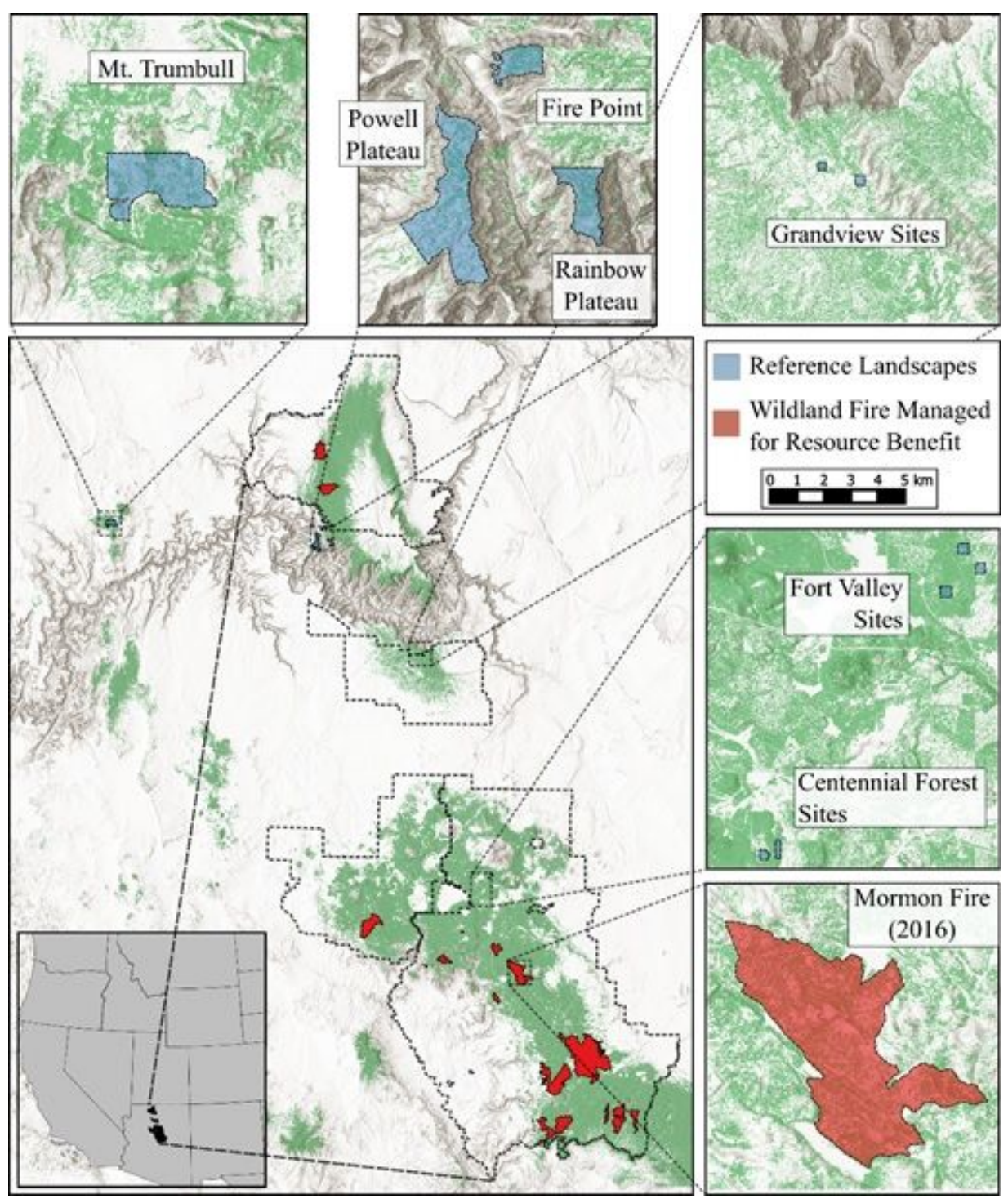

Reference Landscapes

Wildland Fire Managed for Resource Benefit
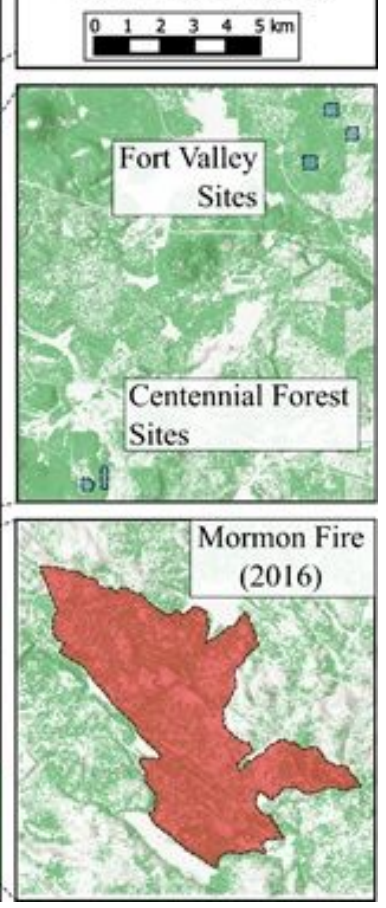

\section{Figure 1}

Reference landscapes include Mt. Trumbull, Powell Plateau, Rainbow Plateau, and Fire Point (ranging in size from 452 to 14,579 ha) and seven smaller sites (ranging in size from 8 to $15 \mathrm{ha}$ ) located at Centennial Forest, Fort Valley, and Grandview (Tusayan Ranger District of the Kaibab National Forest). Also shown are 16 managed wildfires (e.g., Mormon fire) which ranged in size from 450 to 14,000 ha and occurred in years 2015 to 2017. Panel insets show all reference landscapes and one example of wildland fire managed for resource benefit. Overview map shows ponderosa pine distribution according to the Southwest ReGAP classification; insets show classification output of ponderosa canopy cover. 


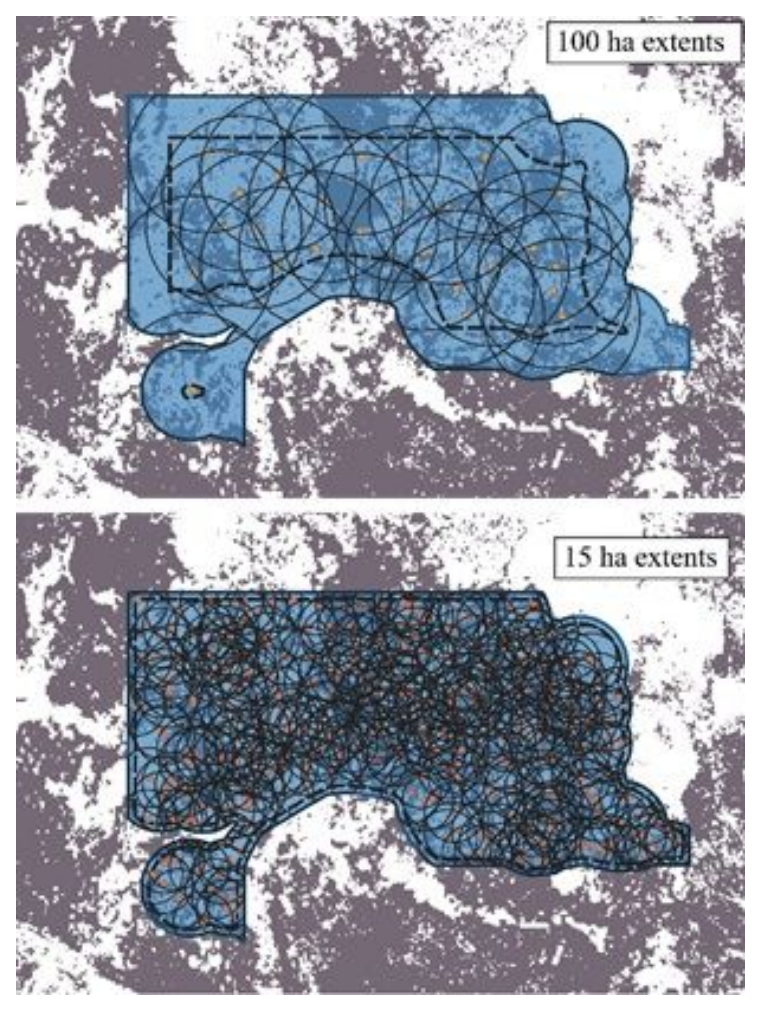

\section{Figure 2}

Example of (A) 100-ha sampled extents and (B) 15-ha sampled extents for the Mt. Trumbull reference landscape. The dark dashed line shows the inward buffering used in the process of creating the sampled extents, within which random points were generated (red dots). and then buffered and clipped to the landscape boundary. Sampled extents were removed if their centroid intersected many other polygons (determined relative to the total number of sampled extents). Extents were removed if their resulting area was less than $75 \%$ of the target extent area. 

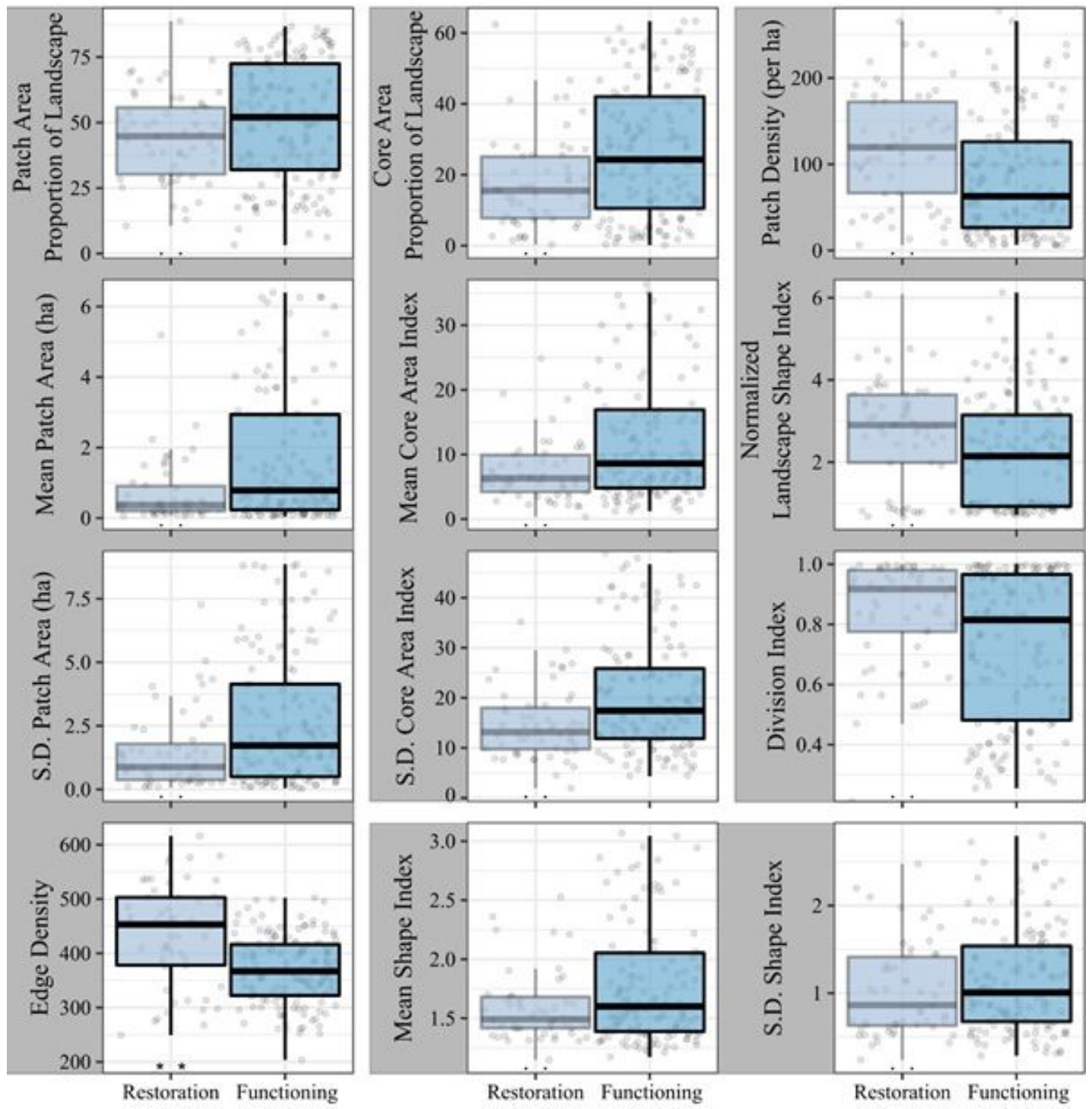

Figure 3

Boxplot comparisons of restoration treatment samples (lighter blue; $n=57$ ) to reference landscapes (darker blue; $\mathrm{n}=$ 148) sampled at approximately 15 -ha extents for $A$ ) area and edge metrics, B) core area metrics, C) aggregation metrics and $D)$ shape metrics. Restoration boxplots are outlined in black if comparison tests were significant $(p<$ 0.01 ), and semi-transparent otherwise. The only significant difference was for edge density. Test results are displayed above the $x$-axis with asterisks for significance in each of the comparison tests (Kolmogorov-Smirnov, Mann-Whitney) and a point otherwise. 


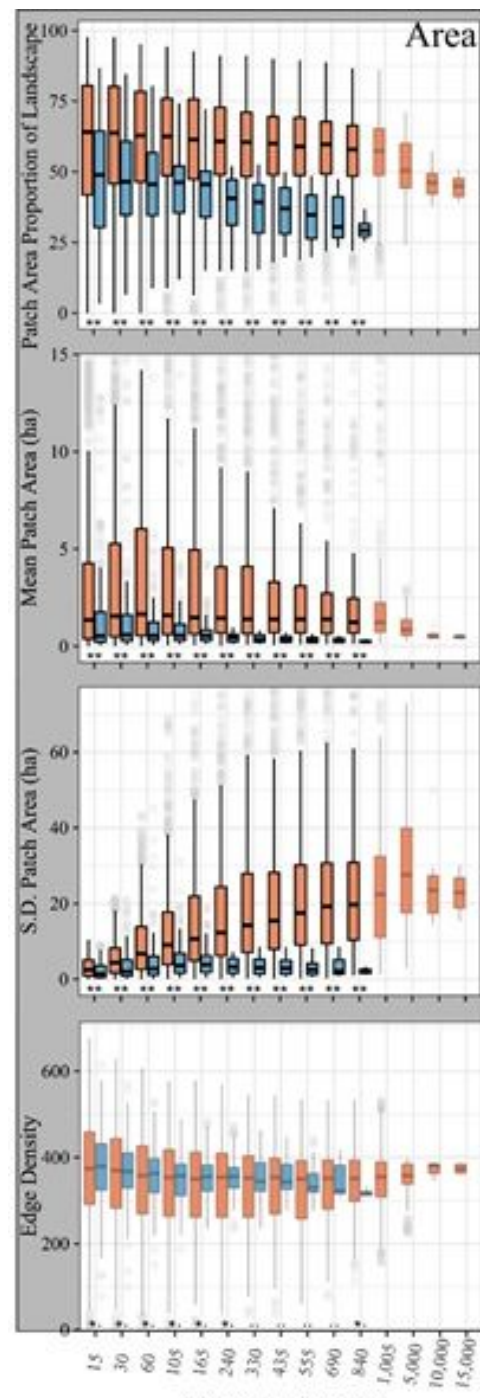

Subsample Extent (ha)
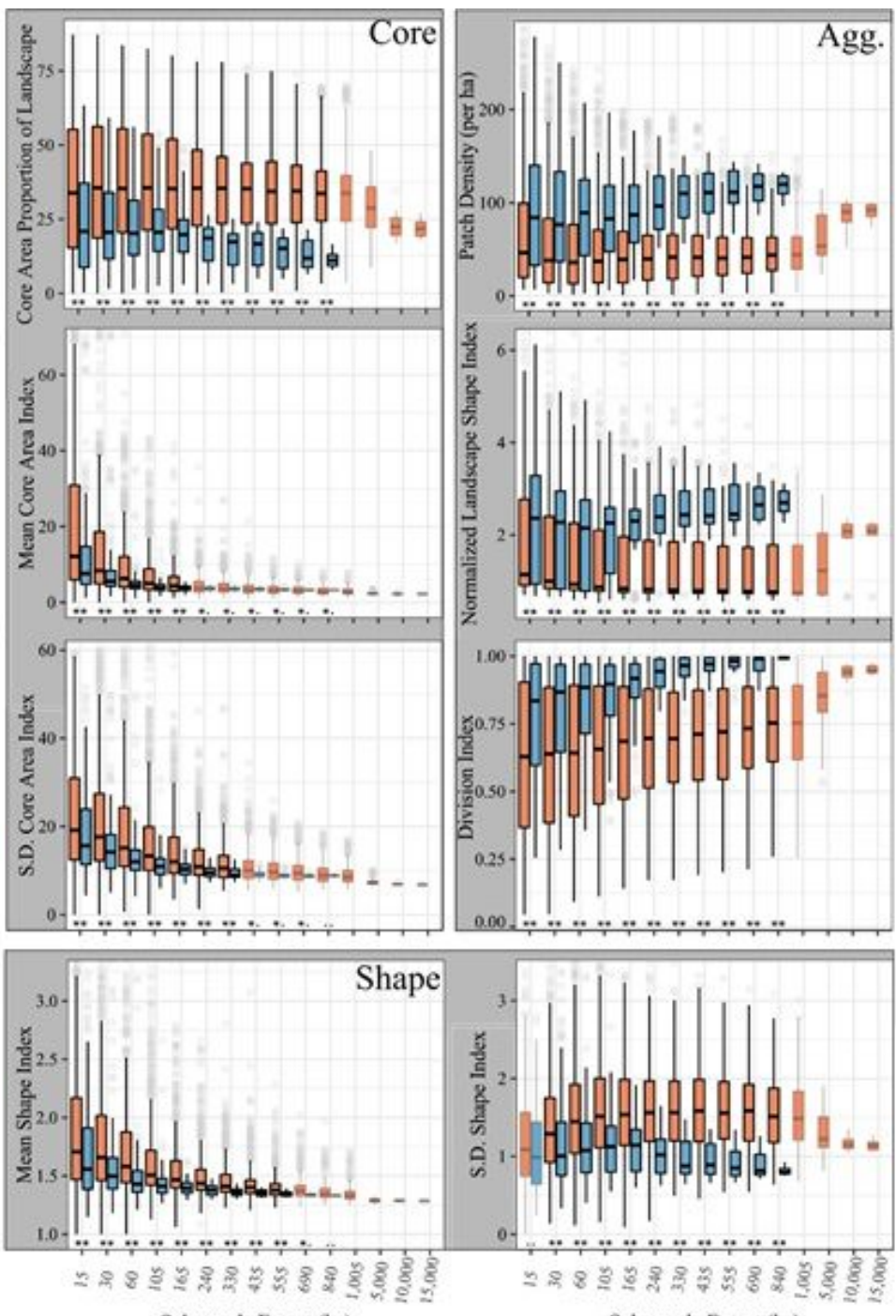

Subsample Extent (ha)

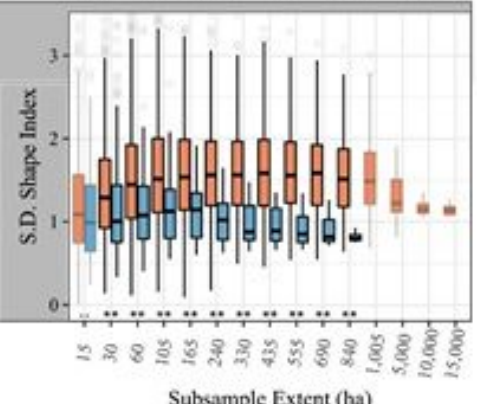

Subsample Extent (ha)

\section{Figure 4}

Comparison of landscape metrics among a gradient of extents within reference landscapes (blue) and managed wildfires (red) for area and edge (Area), core area (Core), aggregation (Agg.), and shape (Shape) metrics. While we show metrics for the largest extents of wildfires, comparisons to reference were only possible up to 840 ha extents. Individual boxplots are outlined in black if both comparison tests were significant $(p<0.01)$, and transparent otherwise. Test results displayed above the x-axis with asterisks for each of the comparison tests (KolmogorovSmirnov, Mann-Whitney). Outlier values are included but transparent to highlight the main distribution of metric values. 

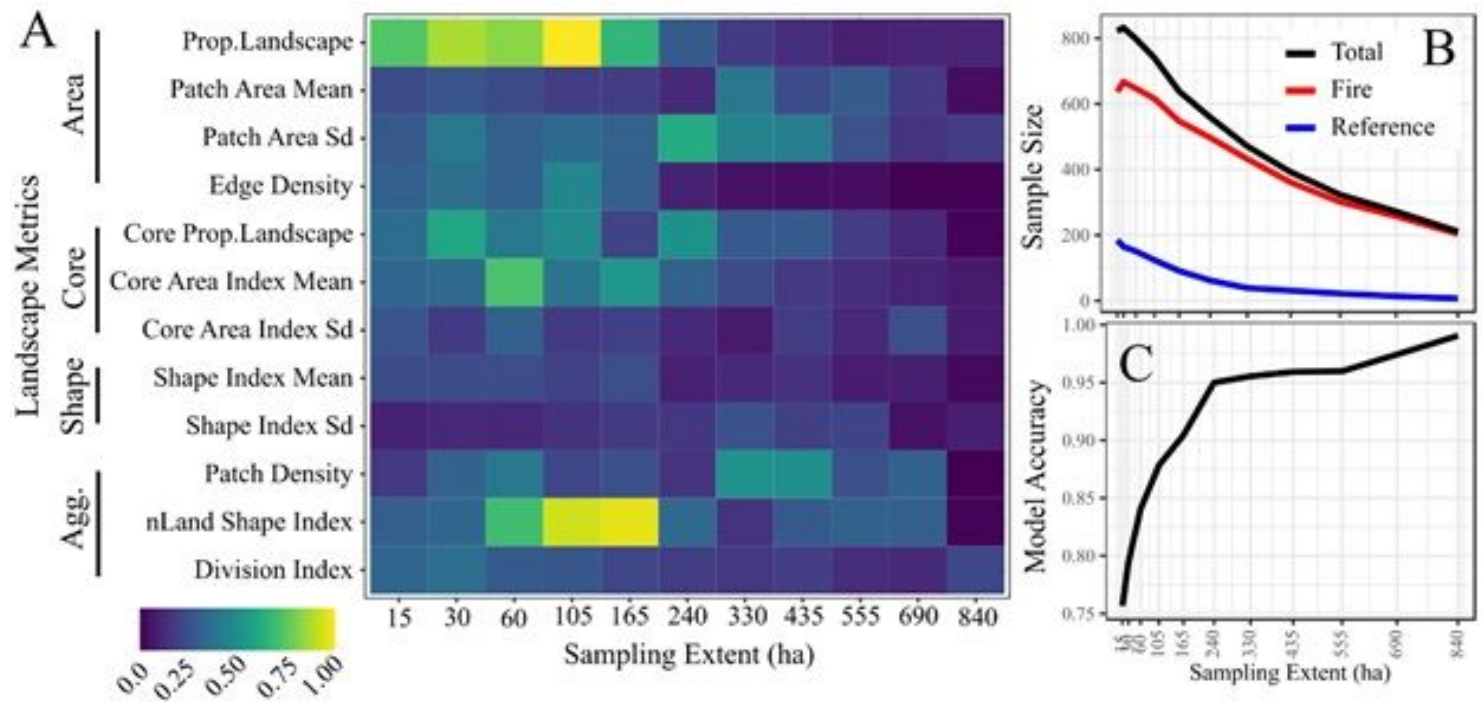

\section{Figure 5}

Heatmap showing variable importance among random forest models for each extent from 15ha to 840ha (A), sample sizes for each landscape extent (B) and overall model accuracy for each scale (C). Variable importance was normalized to a 0 to 1 scale for ease of interpretation. Overall, variables became less important with increasing landscape extent while overall model accuracy increases to nearly $100 \%$, despite having fewer samples to draw from. Area and aggregation metrics remain the most important metric classes among all models. Importance values were re-scaled from 0 to 1 by dividing by the maximum importance value from the model series.

\section{Supplementary Files}

This is a list of supplementary files associated with this preprint. Click to download.

- AppendixAFireTable.docx

- AppendixSummaryTableFormatted.docx

- AppendixCCorrelations.docx 